\title{
Perceived effectiveness of a community policing program in Malaysia: a comparison of socio-demographic factors
}

\begin{abstract}
Rakan COP (Community Oriented Policing) invites the public to become friends of the police through interactive information sharing program. The purpose of this study is to understand the implementation and also the effectiveness of the Rakan COP program developed by Royal Malaysia Police with the aim of maintaining peace and reducing public fear of crime in the Malaysia. Two specific objectives were formed as follows (a) to identify the effectiveness level of the Rakan COP Program and (b) to determine the socio-demographic differences in the effectiveness of the Rakan COP. The questionnaire was adapted based on previous studies in program effectiveness. A total of 384 Rakan COP members in Kuala Lumpur were chosen by cluster sampling techniques based on the characteristics recommended by the Kuala Lumpur Police Contingent Head Quarters. The findings showed that the Rakan COP member provides an excellent assessment towards the effectiveness of the program. However, all socio-demographic factors shows there is no significant different among factors towards the effectiveness of Rakan COP program.
\end{abstract}

Keyword: Community; Community policing; Crime prevention; Program effectiveness; Rakan COP 